\title{
Lime and fertilizer recommendation system for coconut trees ${ }^{1}$
}

\author{
Gustavo Nogueira Guedes Pereira Rosa ${ }^{2}$, Roberto Ferreira de Novais ${ }^{3}$, Victor Hugo Alvarez V. ${ }^{3}$, \\ Nairam Félix de Barros ${ }^{3}$,Ecila Mercês de Albuquerque Villani ${ }^{4}$
}

\begin{abstract}
Fertilizer recommendation to most agricultural crops is based on response curves. Such curves are constructed from field experimental data, obtained for a particular condition and may not be reliable to be applied to other regions. The aim of this study was to develop a Lime and Fertilizer Recommendation System for Coconut Crop based on the nutritional balance. The System considers the expected productivity and plant nutrient use efficiency to estimate nutrient demand, and effective rooting layer, soil nutrient availability, as well as any other nutrient input to estimate the nutrient supply. Comparing the nutrient demand with the nutrient supply the System defines the nutrient balance. If the balance for a given nutrient is negative, lime and, or, fertilization is recommended. On the other hand, if the balance is positive, no lime or fertilizer is needed. For coconut trees, the fertilization regime is divided in three stages: fertilization at the planting spot, band fertilization and fertilization at the production phase. The data set for the development of the System for coconut trees was obtained from the literature. The recommendations generated by the System were compared to those derived from recommendation tables used for coconut crop in Brazil. The main differences between the two procedures were for the P rate applied in the planting hole, which was higher in the proposed System because the tables do not pay heed to the pit volume, whereas the $\mathrm{N}$ and $\mathrm{K}$ rates were lower. The crop demand for $\mathrm{K}$ is very high, and the rates recommended by the System are superior to the table recommendations for the formation and initial production stage. The fertilizer recommendations by the System are higher for the phase of coconut tree growth as compared to the production phase, because greater amount of biomass is produced in the first phase.
\end{abstract}

Key words: Cocos nucifera L., nutrition, modelling.

\section{RESUMO}

\section{Sistema de recomendação de calcário e fertilizantes para a cultura do coqueiro}

As recomendações de fertilizantes utilizadas para a maior parte das culturas são baseadas em curvas de resposta. Ensaios de campo são realizados em determinada região, não sendo os resultados extrapoláveis para outras regiões. $\mathrm{O}$ objetivo desse trabalho foi desenvolver um Sistema de Recomendação de Corretivos e Fertilizantes para a Cultura do Coqueiro baseado no balanço nutricional, no qual, o Sistema considera, para estimar as doses de fertilizantes, a produtividade desejada, a variedade cultivada, a estimativa da disponibilidade de nutrientes no solo, assim como outras formas de adição de nutrientes. O Sistema define o balanço de nutrientes ao comparar a demanda de nutrientes com o seu suprimento. Se o balanço para determinado nutriente for negativo, calcário e, ou, fertilizante são adicionados; se positivo, não há adição. Para a fertilização de coqueiros, o sistema é dividido em três etapas: fertilização da cova

\footnotetext{
Recebido para publicação em março de 2010 e aprovado em dezembro de 2010

${ }^{1}$ Parte da Dissertação apresentada à Universidade Federal de Viçosa pelo primeiro autor para obter o título de mestre. Trabalho financiado pelo CNPq.

2 Engenheiro-Agrônomo, Mestre. Fertilizantes Heringer S/A, BR 262, Km 39,4, Ponte da Aldeia, 36900-000, Manhuaçu, MG, Brasil. gustavongpr@ hotmail.com

${ }^{3}$ Engenheiros-Agrônomos, Ph. Doctor. Departamento de Solos, Universidade Federal de Viçosa. Av. P. H. Rolfs, s/n, 36570-000 Viçosa, MG, Brasil. rfnovais@ufv.br; vhav@ufv.br ${ }^{4}$ Engenheiro Florestal, Ph. Doctor. Departamento de Solos, Universidade Federal de Viçosa. Av. P. H. Rolfs, s/n, 36570-000 Viçosa, MG, Brasil.nfbarros@ufv.br

5 Engenheira-Agrônoma, Doutora. Pós doutoranda do Departamento de Solos, Bolsista da FAPEMIG. Universidade Federal de Viçosa, Av. P. H. Rolfs, s/n, 36570-000, Viçosa,MG, Brasil. ecilavillani@hotmail.com
}

Rev. Ceres, Viçosa, v. 58, n.1, p. 90-99, jan/fev, 2011 
de plantio, fertilização de formação e início de produção e fertilização de produção. A quantidade do nutriente exigida pela planta menos o seu suprimento por fontes diversas gera a recomendação de fertilizantes. As informações necessárias para o desenvolvimento do Sistema foram obtidas na literatura. Foram comparados os resultados obtidos pelo Sistema com as principais tabelas de recomendação de fertilizantes para o coqueiro no Brasil. As principais diferenças entre os dois procedimentos foram para a dose de $\mathrm{P}$ aplicada no plantio, que foi maior no Sistema proposto porque as tabelas não consideram o volume da cova, entretanto, para $\mathrm{N}$ e K, foram menores. A demanda por $\mathrm{K}$ pela cultura é elevada e os valores recomendados pelo Sistema são superiores àqueles recomendados pelas tabelas no estádio de formação e produção inicial. As recomendações de fertilizantes pelo Sistema, que foram maiores durante a fase de formação do coqueiro, comparativamente à fase de produção devem-se ao fato de que maior quantidade de biomassa é produzida na primeira fase.

Palavas-chave: Cocus nucifera L., nutrição, modelagem

\section{INTRODUCTION}

Present recommendation tables of lime and fertilizers for crops, in spite of their relative accuracy and easiness of use, are based on crop response curves and increasing fertilizer and calibration, and on the experience of specialists of the area. These tables do work alright, but there might be a great difference between a mistake from a theoretical point of view and a success from a practical viewpoint, and in terms of evolution it would definitely be unsatisfactory to work without scientific bases. This is the reason for the need to develop a lime and fertilizer recommendation system with scientific foundation, in a more mechanist than empirical adjustment. A lime and fertilizer recommendation system, developed on the base of a particular culture nutritional balance, allows a broader use and a safer evolution. The distance to the regional model becomes greater and greater, and a universal model is being approached (Novais \& Smyth, 1999).

One of the objectives of the adjustment is to give rise to doubts and questions that call for solutions and answers, thus indicating the direction for future research (Prezotti, 2001).

There is already considerable knowledge on fertilization of annual crops. For perennial crops, on the other hand, particularly of tree species, comprehension is not as rich, due to factors like: long lifetime of plants; greater environmental, climatic, and soil interference; nutrient dynamics in the soil-plant system; and the kind of harvested product. These difficulties challenge specialists and researchers that work with perennial crops to strive for a more profound understanding of the climate-plant-soil relationships (Barros et al., 1996).

There is a great variation among fertilizer tables for coconut trees, suggesting that the real crop nutrient demand is actually unknown (Medina, 1980; Magat, 1991; Madeira et al., 1998; Sobral, 1998, and Rosa Jr, 2000). Besides, there are differences in the root system distribution, stem growth rate, leaf emission, and the fruit productivity and composition of the two coconut varieties, dwarf and giant, and the hybrid dwarf $\mathrm{x}$ giant. Consequently, the System provides a specific recommendation for the hybrid and another for the dwarf. The giant coconut is a more robust variety, although less productive, and is not included in the System because it is normally cultivated without fertilization (Sobral, 1998).

The System proposed in this study estimates the nutrient quantity that is to be applied by fertilization considering the difference between the nutrient quantity required by the plant, and the nutrient supply by the soil volume penetrated by the roots. The increment of nutrients through other sources like organic fertilizers, recycled plant parts in the soil, and rain are included, too. Wherever a particular information required for the development of the System was not available, the value was estimated consisting in the behavior of other, more investigated perennial plants.

The objective of this study was the development a lime and fertilizer recommendation model for coconut crop, according to the plant demands, taking management, target productivity, crop variety, root system distribution, nutrient increment by rain and organic fertilization, as well as nutrient availability in the soil into consideration.

\section{MATERIAL AND METHODS}

\section{Fertilization at the planting spot}

Fertilization in the planting pit has the aim of rising the nutrient contents in the hole volume up to a certain critical level $(\mathrm{CrL})$. Nitrogen was not considered in the routine analysis, since its availability could not be estimated consistently, due to the organic matter content of the soil. Fertilization aims at providing a dose of $300 \mathrm{mg} \mathrm{dm}^{-3}$ of $\mathrm{N}$ to the soil. 
The CrL of implantation for $\mathrm{P}$ and $\mathrm{S}$ varies according to the soil capacity factor (Prezotti, 2001). The CrLs of these nutrients are estimated by reminiscent phosphorus (PR-60) as a measure for the buffer capacity or strength of the soil element.

The recommended planting pit is $80 \times 80 \times 80 \mathrm{~cm}$, and the nutrient quantity to be applied is proportional to its volume. Any alterations of the hole volume will alter the fertilizer quantity recommended by the System to maintain the same nutrient concentration $(\mathrm{CrL})$ in the soil volume of the pit (Tables 1 and 2).

The use of dung, castor bean cake, coconut or coffee husks and bone meal is recommended and considered in the calculation of nutrient supply. Therefore, the balance of the nutrient contents of these materials is included in the System (Table 3). Organic fertilization has the advantage of acting as a fertilizer of slow release, constantly setting nutrients free, as well as improving the physical and biological soil conditions.

At the formation and beginning production stage, fruit production is still low, and the plant invests a great amount of nutrients into the root system and stem growth (Ouvrier, 1990). The hybrid coconut plant begins production at an age of approximately 42 months, and reaches the adult age at 84 months. The immobilized nutrient quantities in the plant, a sum of the immobilized contents in the roots, stem, leaves, and fruit bunches (Ouvrier, 1990) are used to adjust the nutrient demand equations according to the age of the hybrid coconut tree.

Dwarf coconut trees are considered to attain adult age after 72 months (six years) and begin fruit production at the age of three years. Nutrient demand equations according to the age of the dwarf coconut tree, as

Table 1. Critical levels of implantation (in soil of the planting hole) of potassium, calcium, and magnesium

\begin{tabular}{lc}
\hline Nutrient - extractor & $\begin{array}{c}\text { Critical level } \\
\mathbf{m g ~ d m}^{-3}\end{array}$ \\
\hline $\mathrm{K}-\mathrm{Mehlich}-1$ & 250 \\
$\mathrm{Ca}-\mathrm{KCl} 1 \mathrm{~mol} \mathrm{~L}^{-1}$ & 460 \\
$\mathrm{Mg}-\mathrm{KCl} 1 \mathrm{~mol} \mathrm{~L}^{-}$ & 140 \\
\hline
\end{tabular}

Source: Prezotti (2001). discussed later, allow an estimation of the nutrient accumulation in the vegetative plant part without the fruits. The estimation of vegetative biomass production is founded on the data for hybrid coconut trees in good state of development. Data of dry matter production of the dwarf coconut tree were estimated in relation to some characteristics of this variety. The leaf emission of the dwarf coconut per year (18) is 1.3 times higher than the one of the hybrid (14) although the leaf area of the dwarf is $80 \%$ smaller than that of the hybrid. A 1.8 factor was used to convert the leaf dry matter production of the hybrid into that of the dwarf. The stem growth is smaller (approximately $1 / 3$ of the hybrid growth) and the root growth was estimated $70 \%$ below that of the giant and the hybrid coconut, due to the smaller explored soil volume (70\% less volume).

A young plant is not able to produce a large number of fruits, and the user should estimate the production around 20 fruits in the $3^{\text {rd }}, 40$ in the $4^{\text {th }}, 80$ in the $5^{\text {th }}$, and from the $6^{\text {th }}$ year on, when the plant is at the top of its production capacity with up to 160 fruits per year. With the definition of the production, it is possible to estimate the total nutrient demand according to the age of the plant.

If the dry matter production of each constituent of the young dwarf or hybrid coconut plant in good growth conditions is multiplied with each nutrient content, the immobilized nutrient content of each constituent according to the age is obtained. The sum of these values is the total accumulated nutrient content according to the age (Tables 4 and 5).

After planting, the System estimates the fertilizer quantity to be applied by the difference of the nutrient content to be accumulated in the following year, until the plant attains adult age. The required nutrient quantities of coconut trees for healthy growth are estimated in function of the biomass production variation, from the first to the second year, and so on, until a stable production of the crop is attained.

The division in three age groups of the nutrient accumulation equations according to the age before the plant reaches adult age, is result of the different growth rates of the plant. At a first stage, nutrient accumulation is

Table 2. Estimate of the critical implantation levels $\left(\mathrm{mg} \mathrm{dm}^{-3}\right)$ in the soil of the planting hole for phosphorus and sulfur, in function of the PR - $60^{(1)}\left(\mathrm{mg} \mathrm{L}^{-1}\right)$ and the extractor in use

\begin{tabular}{llc}
\hline Nutrient-extractor & Equation & $\mathbf{R}^{2}$ \\
\hline P-Mehlich & $\mathrm{CrL}\left(\right.$ Mehlich-1) $=82.35-0.2744 \mathrm{PR}^{(1)}-60+0.1035$ PR-60 \\
P-Resina & $\mathrm{CrL}($ Resina $)=92.10+1.70$ PR-60 & 0.520 \\
$\mathrm{~S}-\mathrm{Ca}\left(\mathrm{H}_{2} \mathrm{PO}_{4}\right)_{2}$ HOAc & $\mathrm{CrL}\left(\mathrm{Ca}\left(\mathrm{H}_{2} \mathrm{PO}_{4}\right)_{2}\right.$ in $\left.\mathrm{HOAc}\right)=10.80+1.54 \mathrm{PR}-60$ & 0.722 \\
\hline
\end{tabular}

Source: (Prezotti, 2001). (1) Reminiscent $\mathrm{P}$ is a measure of the $\mathrm{P}$ soil capacity factor (PCF) and expresses $\mathrm{P}$ in equilibrium-state, which is attained when $60 \mathrm{mg} \mathrm{L}^{-1}$ of $\mathrm{P}$ in a $10 \mathrm{mmol} \mathrm{L}^{-1} \mathrm{CaCl}_{2}$ solution are shaken with a soil sample during $1 \mathrm{~h}$, in a soil: solution ratio of 1:10 (Novais \& Smyth, 1999). ${ }^{(2)}$ If the user does not have the PR-60 value available, this value is estimated according to the clay content by the equation: PR-60 = 53.810 - 1.1145 Arg + $0.0066 \mathrm{Arg}^{2}$ (Prezotti, 2001).

Rev. Ceres, Viçosa, v. 58, n.1, p. 90-99, jan/fev, 2011 
slow, (until 18 months for the hybrid, and 16 for the dwarf). Between 19 and 40, and 17 and 42 months, respectively, growth is intensive, so both the hybrid and dwarf coconut tree accumulate enormous nutrient amounts every year. After 40 months (beginning of flowering) until 84 months (adult age) the nutrient accumulation of the hybrid sinks again, due to the lower growth rate, although there is a demand for fruit formation.

For the adjustment of the equations to estimate the quantity of nutrients and sodium which is immobilized in the vegetative part of the dwarf coconut tree, according to the age, the nutrient contents of the roots, leaves, and stem of the dwarf coconut tree were considered to be equal to those of the hybrid at this stage.

\section{Efficiency of nutrient recycling by the plant}

The efficiency of recycling (ER) of soil nutrients by the plant varies according to the age, and for some nutrients, it varies also according to the soil capacity factor (reminiscent $\mathrm{P}$ or clay content). Young plants present a

Table 3. Nutrient and Sodium contents in some organic fertilizers (dry matter) which can be used

\begin{tabular}{lcccccc}
\hline \multirow{2}{*}{ Fertilizer } & $\mathbf{N}$ & $\mathbf{P}$ & $\mathbf{K}$ & $\mathbf{C a}$ & $\mathbf{M g}$ & $\mathbf{N a}$ \\
\cline { 2 - 7 } & \multicolumn{7}{c}{$\mathbf{g ~ k g ~}^{-1}$} \\
\hline Cattle dung $^{(1)}$ & 17.6 & 3.9 & 20.3 & 10.9 & 4.4 & 5.2 \\
Pig dung( $^{(1)}$ & 23.2 & 20.9 & 16.2 & 32.5 & 7.7 & 9.6 \\
Chicken dung $^{(1)}$ & 44.5 & 17.6 & 29.5 & 35.8 & 5.3 & 8.5 \\
Poultry litter $^{(1)}$ & 35.6 & 13.3 & 19.9 & 23.1 & 5.0 & 6.7 \\
Bone meal $^{(1)(2)}$ & 15 & 87.0 & - & 70 & 7.0 & - \\
Castor cake $^{(2)}$ & 54.4 & 8.3 & 12.8 & 5.0 & 2.0 & - \\
Coffea husk $^{(3)}$ & 18.0 & 1.6 & 32.3 & 4.4 & 1.6 & - \\
Coconut husk $^{(4)}$ & 2.4 & 0.2 & 17.5 & 0.7 & 0.5 & 1.5 \\
\hline Source: Ada(t)d
\end{tabular}

Source: Adapted of Kiehl (1985) ${ }^{(1)}$, Alvarez V. \& Ribeiro (1999) ${ }^{(2)}$, Prezotti (2001)(3) and Ouvrier \& Taffin (1985) ${ }^{(4)}$.

Table 4. Equations to estimate the nutrient and sodium quantity immobilized in the entire plant of the hybrid coconut (g/plant) according to the age (month) for a healthy growth from planting to the adult age (138 to 160 plants/ha)

\begin{tabular}{|c|c|c|c|c|c|c|}
\hline Element & $\begin{array}{c}\text { Equation } \\
\text { (Implantation } \\
\text { - } 18 \text { month) }\end{array}$ & $\mathbf{R}^{2}$ & $\begin{array}{c}\text { Equation } \\
(19-40 \text { month })\end{array}$ & $\mathbf{R}^{2}$ & $\begin{array}{c}\text { Equation } \\
\text { (41-84 month) }\end{array}$ & $\mathbf{R}^{2}$ \\
\hline$\overline{\mathrm{N}}$ & $\hat{y}=2.0354 \mathrm{e}^{0.1614 x}$ & 0.9753 & $\hat{y}=116.720-24.147 x+1.1045 x^{2}$ & 0.9985 & $\hat{y}=2.6440 x^{1.6308}$ & 0.9251 \\
\hline $\mathrm{P}$ & $\stackrel{\hat{y}}{=}=0.2418 \mathrm{e}^{0.1752 x}$ & 0.9662 & $\hat{y}=20.458-4.396 x+0.2052 x^{2}$ & 0.9993 & $\hat{y}=2.3599 x^{1.2044}$ & 0.8029 \\
\hline $\mathrm{K}$ & $\hat{\mathrm{y}}=3.0771 \mathrm{e}^{0.1576 \mathrm{x}}$ & 0.9970 & $\hat{\mathrm{y}}=175.980-35.11 \mathrm{x}+1.5415 \mathrm{x}^{2}$ & 0.9970 & $\hat{\mathrm{y}}=1.5735 \mathrm{x}^{1.8484}$ & 0.9220 \\
\hline $\mathrm{Ca}$ & $\hat{\mathrm{y}}=0.7292 \mathrm{e}^{0.1695 x}$ & 0.9814 & $\hat{y}=75.905-14.931 x+0.6169 x^{2}$ & 0.9953 & $\hat{\mathrm{y}}=2.9216 \mathrm{x}^{1.3957}$ & 0.9706 \\
\hline $\mathrm{Mg}$ & $\hat{\mathrm{y}}=0.3208 \mathrm{e}^{0.1824 \mathrm{x}}$ & 0.9786 & $\hat{y}=59.573-11.550 x+0.4577 x^{2}$ & 0.9931 & $\hat{\mathrm{y}}=5.5027 \mathrm{x}^{1.1419}$ & 0.8989 \\
\hline $\mathrm{Na}$ & $\hat{\mathrm{y}}=0.1464 \mathrm{e}^{0.1821 \mathrm{x}}$ & 0.9530 & $\hat{y}=17.843-3.664 x+0.1625 x^{2}$ & 0.9974 & $\hat{y}=0.3087 x^{1.7029}$ & 0.9106 \\
\hline $\mathrm{Cl}$ & $\hat{\mathrm{y}}=1.4969 \mathrm{e}^{0.1597 \mathrm{x}}$ & 0.9959 & $\hat{\hat{y}}=88.450-17.514 x+0.7743 x^{2}$ & 0.9959 & $\hat{\mathrm{y}}=0.5572 \mathrm{x}^{1.9477}$ & 0.9354 \\
\hline S & $\hat{\mathrm{y}}=0.1985 \mathrm{e}^{0.1552 \mathrm{x}}$ & 0.9788 & $\hat{y}=9.272-1.8961 x+0.0868 x^{2}$ & 0.9788 & $\hat{y}=0.2103 x^{1.6315}$ & 0.9002 \\
\hline
\end{tabular}

Source: Ouvrier (1990).

Table 5. Equations to estimate the nutrient and sodium quantity immobilized in the aerial plant part of the dwarf coconut (g/plant) according to the age (month) for a healthy growth from planting to the adult age (177 to 205 plants/ha)

\begin{tabular}{|c|c|c|c|c|c|c|}
\hline Element & $\begin{array}{c}\text { Equation } \\
\text { (Implantation } \\
\text { - } 16 \text { month) }\end{array}$ & $\mathbf{R}^{2}$ & $\begin{array}{c}\text { Equation } \\
(17-42 \text { month })\end{array}$ & $\mathbf{R}^{2}$ & $\begin{array}{c}\text { Equation } \\
\text { (43-72 month) }\end{array}$ & $\mathbf{R}^{2}$ \\
\hline $\mathrm{N}$ & $\hat{y}=1.9840 e^{0.1537 x}$ & 0.9718 & $\hat{y}=67.9910-14.6550 x+0.7344 x^{2}$ & 0.9996 & $\hat{y}=0.3911 x^{1.9736}$ & 0.9205 \\
\hline $\mathrm{P}$ & $\hat{\mathrm{y}}=0.2649 \mathrm{e}^{0.1719 \mathrm{x}}$ & 0.9465 & $\hat{y}=15.2360-3.3981 x+0.1735 x^{2}$ & 0.9996 & $\hat{y}=0.2663 x^{1.6656}$ & 0.8971 \\
\hline $\mathrm{K}$ & $\hat{y}=3.1294 e^{0.1485 x}$ & 0.9731 & $\hat{\mathrm{y}}=89.0350-18.8900 \mathrm{x}+0.9531 \mathrm{x}^{2}$ & 0.9994 & $\hat{y}=0.7161 x^{1.8665}$ & 0.9418 \\
\hline $\mathrm{Ca}^{(1)}$ & $\stackrel{\hat{y}}{=}=0.6965 \mathrm{e}^{0.1651 x}$ & 0.9835 & $\hat{\mathrm{y}}=64.9510-12.5980 \mathrm{x}+0.5145 \mathrm{x}^{2}$ & 0.9942 & $\hat{\mathrm{y}}=0.1118 \mathrm{x}^{2.1265}$ & 0.9076 \\
\hline $\mathrm{Mg}^{(1)}$ & $\hat{y}=0.3031 e^{0.1769 x}$ & 0.9748 & $\hat{y}=40.0290-7.9111 x+0.3271 x^{2}$ & 0.9953 & $\hat{y}=0.1757 x^{1.8788}$ & 0.8453 \\
\hline $\mathrm{Na}$ & $\stackrel{\hat{y}}{=}=0.1436 \mathrm{e}^{0.1774 x}$ & 0.9475 & $\hat{\mathrm{y}}=12.0650-2.5785 \mathrm{x}+0.1228 \mathrm{x}^{2}$ & 0.9988 & $\hat{\mathrm{y}}=0.0223 \mathrm{x}^{2.2562}$ & 0.9574 \\
\hline $\mathrm{Cl}$ & $\hat{y}=1.5053 e^{0.1504 x}$ & 0.9588 & $\hat{y}=14.9180-9.4805 x+0.4759 x^{2}$ & 0.9983 & $\hat{y}=0.5053 x^{0.1504}$ & 0.9806 \\
\hline$S^{(1)}$ & $\hat{\mathrm{y}}=0.1829 \mathrm{e}^{0.1539 \mathrm{x}}$ & 0.9798 & $\hat{y}=8.7285-1.7495 x+0.0783 x^{2}$ & 0.9975 & $\hat{y}=0.1829 x^{0.1539}$ & 0.9099 \\
\hline
\end{tabular}

Source: Adapted of Ouvrier (1990).

(1)For the nutrients $\mathrm{Ca}, \mathrm{Mg}$, and $\mathrm{S}$ the equations to estimate nutrient accumulation should be used from planting to the age of 20 months. 
lower ER than the adult plants (Table 6), due to the smaller root system, mainly regarding nutrients of low mobility in the soil, such as P (Prezotti, 2001). This behavior explains the high nutrient recommendation in relation to the quantity the plant accumulates in its biomass.

The ER of nutrients for a plant is calculated by the difference between the immobilized nutrients in the fertilized plant and the immobilized quantity in the control, divided by the applied nutrient dose, that is, the uptake of the applied nutrient by the plant. The estimate values of the ER were considered the constant during the youth stage, and variations according to varying applied nutrient doses were not taken into account.

\section{Nutrient quantity in the soil required by plants}

The nutrient quantity in the soil required by the plant is obtained with the division of the immobilized nutrient quantity in the biomass (demand) by the ER. The explored soil volume at the adult stage is known for the dwarf (Cintra et al., 1992), and the giant variety (Cintra et al., 1993). The soil volume hybrid trees explore is considered equal to that of giant coconut, for want of data. The soil volume young coconut plants explore is assessed according to the root distribution radius from the stem and the depth obtained at adult age. An yearly increase of $5 \mathrm{~cm}$ is estimated for the depth and $20 \mathrm{~cm}$ for the radius until the adult age (Table 7).

\section{Nutrient supply}

Nutrient supply is calculated by the sum of the nutrient quantities available in the soil (Table 8), those added by rain (Table 9), and by organic fertilization (Table 3 ).

Nutrient contents determined by soil analysis do not indicate, quantitatively, what a plant can adsorb. However, if the nutrient recycling rate from the soil by the extractor is known, that is, the relation between the recycled nutrient quantity by the extractor and the nutrient quantity applied to the soil, it is possible to estimate the available quantity for plants, according to the soil volume the roots explore (Tables 7). For the nutrients $\mathrm{P}$ and $\mathrm{S}$, whose behavior is influenced by the soil capacity factor, the nutrient recycling rates for a determined factor by the extractor vary according to the PR-60 (Novais \& Smyth, 1999). When the PR-60 value is not known, it can be estimated according to the clay content (Prezotti, 2001). To obtain mean recycling values of nutrients for a particular extractor, information from different studies, carried out in soils with different characteristics were combined. It is assumed that the organic soil matter does remain constant, and that $\mathrm{N}$ is supplied by the rain, crop residues and organic fertilizers, without including the released nutrients by mineralization of the organic matter.
The application of high $\mathrm{P}$ doses in the planting hole causes a residual effect in the soil.

Regarding nutrient addition, the analysis of rain and yearly precipitation of each region provide the necessary information for the calculation of the System. Data of the region Aracruz, State of Espirito Santo, are shown as an example (Table 9).

\section{Nutrient quantity to be applied (fertilization recommendations)}

The nutrient quantity that is to be applied (recommended fertilization) is calculated by the difference between the nutrient quantity in the soil required by the plant to establish a determined biomass (demand-Tables 4 and 5, divided by the ER-Table 6) and the nutrient supply in the soil (Table 8) through organic fertilization (Table 3), and rain (Table 9).

The lime quantity to be applied is calculated by the base saturation method (Alvarez V. \& Ribeiro, 1999) with the formula: $\mathrm{LD}=\left(\mathrm{V}_{2}-\mathrm{V}_{1}\right) \mathrm{T} / 100$ where $\mathrm{LD}=$ lime demand in $\mathrm{t} / \mathrm{ha}, \mathrm{V}_{1}=$ initial soil base saturation, in $\%, \mathrm{~V}_{2}=$ desired saturation, in \%, and $\mathrm{T}=\mathrm{CTC}$ to $\mathrm{pH} 7.0$, in $\mathrm{cmol}_{\mathrm{c}} \mathrm{dm}^{-3}$. For the coconut crop, an elevation of the $\mathrm{V}_{2}$ to $60 \%$ is desirable. The formula: $\mathrm{LQ}=\mathrm{LD} \times \mathrm{CS} / 100 \times \mathrm{DI} / 20 \times 100 /$ RSTN is used for the calculation of the lime quantity to be applied, where $\mathrm{LQ}=$ the lime quantity, in $\mathrm{t} / \mathrm{ha} ; \mathrm{CS}=$ covered surface, in \%, calculated according to the soil area explored by the plants (Tables 7 and 8 ) and the number of plants per ha; DI = depth of incorporation (since lime is surface applied, a DI of $5 \mathrm{~cm}$ is assumed), in $\mathrm{cm}$; and RSTN = relative strength of total neutralization, in \%.

When the base saturation method recommends certain lime quantities that provide $\mathrm{Ca}$ and $\mathrm{Mg}$ doses that are higher or equal to the System to supply the $\mathrm{Ca}$ and $\mathrm{Mg}$ plant demand, these nutrients are not necessary. When the base saturation method recommends $\mathrm{Ca}$ or, which is common, lower $\mathrm{Mg}$ quantities than the System, these nutrients must be supplied by other sources, as for example magnesium sulfate.

\section{Fertilization of adult plants}

When the plants reach adult age, the explored soil volume by the root system and the number of leaves become constant; the annual growth of the stem is constant (Table 10 ), and the greatest demand of nutrients is on account of the fruit cluster production (Tables 11 and 12 ).

At this stage, the annual nutrient demand of the adult plant is the sum of the immobilized nutrient quantity in the stem and the immobilized nutrient quantity in the fruit clusters for a determined productivity (Tables 11 and 12). Roots and leaves are not included in the evaluation of this stage, since it is assumed that these parts, when formed, will be supplied by recycling of dead leaves and roots. 
Table 6. Recycling efficiency (ER) of nutrients and sodium by the young and the adult plant

\begin{tabular}{|c|c|c|}
\hline \multirow{2}{*}{ Element } & Young plant & Adult plant \\
\hline & \multicolumn{2}{|c|}{$\%$} \\
\hline $\mathrm{N}$ & $60^{(1)}$ & 70 \\
\hline $\mathrm{P}$ & $\hat{\mathrm{ER}}=4.00+0.40(\mathrm{PR}-60)$ & $10.00+0.40(\mathrm{PR}-60)$ \\
\hline $\mathrm{K}$ & $65^{(2)}$ & 70 \\
\hline $\mathrm{Ca}$ & $45^{(3)}$ & 50 \\
\hline $\mathrm{Mg}$ & $55^{(4)}$ & 60 \\
\hline $\mathrm{Na}$ & $65^{(5)}$ & 70 \\
\hline $\mathrm{Cl}$ & 55 & 60 \\
\hline $\mathrm{S}$ & $\hat{\mathrm{E} R}=7.80+0.44(\mathrm{PR}-60)$ & $\hat{\mathrm{ER}}=11.80+0.44(\mathrm{PR}-60)$ \\
\hline
\end{tabular}

Table 7. Soil volume and explored area per hybrid and dwarf coconut plant until the adult age

\begin{tabular}{|c|c|c|c|c|c|c|}
\hline Age & Depth & Radius & Area & $\begin{array}{l}\text { Volume } \\
0-20 \mathrm{~cm}\end{array}$ & $\begin{array}{c}\text { Volume } \\
20-60 \mathrm{~cm}\end{array}$ & $\begin{array}{c}\text { Total } \\
\text { Volume }\end{array}$ \\
\hline \multirow[t]{2}{*}{ month } & \multicolumn{2}{|c|}{ m } & $\mathbf{m}^{2}$ & \multicolumn{3}{|c|}{$\mathbf{d m}^{3}$} \\
\hline & \multicolumn{6}{|c|}{ hybrid } \\
\hline 12 & 0.30 & 0.60 & 1.13 & 226 & 113 & 339 \\
\hline 24 & 0.35 & 0.80 & 2.01 & 402 & 301 & 703 \\
\hline 36 & 0.40 & 1.00 & 3.14 & 628 & 628 & 1,126 \\
\hline 48 & 0.45 & 1.20 & 4.52 & 904 & 1,130 & 2,034 \\
\hline 60 & 0.50 & 1.40 & 6.15 & 1,231 & 1,846 & 3,077 \\
\hline 72 & 0.55 & 1.60 & 8.04 & 1,608 & 2,813 & 4,421 \\
\hline \multirow[t]{2}{*}{84} & 0.60 & 1.80 & 10.17 & 2,035 & 4,069 & 6,104 \\
\hline & \multicolumn{6}{|c|}{ dwarf } \\
\hline 12 & 0.35 & 0.50 & 0.79 & 157 & 118 & 275 \\
\hline 24 & 0.40 & 0.70 & 1.54 & 308 & 308 & 616 \\
\hline 36 & 0.45 & 0.90 & 2.54 & 509 & 636 & 1,145 \\
\hline 48 & 0.50 & 1.10 & 3.80 & 760 & 1,140 & 1,900 \\
\hline 60 & 0.55 & 1.30 & 5.31 & 1,061 & 1,857 & 2,918 \\
\hline 72 & 0.60 & 1.50 & 7.07 & 1,413 & 2,826 & 4,239 \\
\hline
\end{tabular}

Source: Cintra et al. (1992) e Cintra et al. (1993).

Table 8. Equations to estimate the nutrient recovery rate by the respective extractors and equations to estimate the residual $\mathrm{P}$, according to the applied $\mathrm{P}$ dose and the equilibrium-state, for the Mehlich-1 and Resina extractors

\begin{tabular}{lccc}
\hline Nutrient & Extractor & Equations & $\mathbf{R}^{2}$ \\
\hline $\mathrm{P}^{(1)}$ & Mehlich-1 & $\mathrm{P}_{\text {rec }} / \mathrm{P}_{\text {aplic }}=0.1647-0.0005487 \mathrm{PR}-60+0.0002069 \mathrm{PR}-60^{2}$ & 0.520 \\
$\mathrm{P}^{(1)}$ & Resina & $\mathrm{P}_{\text {rec }}=-1.8184+0.2414 \mathrm{P}_{\text {aplic }}$ & 0.816 \\
$\mathrm{P}^{(1)}$ & Resina & $\mathrm{P}_{\text {rec }} / \mathrm{P}_{\text {aplic }}=0.1842+0.0034 \mathrm{PR}-60$ & 0.722 \\
$\mathrm{~K}^{(1)}$ & $\mathrm{K}_{\text {rec }}=4.0052+0.7678 \mathrm{~K}_{\text {aplic }}$ & 0.956 \\
$\mathrm{Ca}^{(1)}$ & $\mathrm{Mehlich-1}$ & $\mathrm{Ca}_{\text {rec }}=0.2495+0.7661 \mathrm{Ca}_{\text {aplic }}$ & 0.918 \\
$\mathrm{Mg}^{(1)}$ & $\mathrm{KCl}$ & $\mathrm{Mg}_{\text {rec }}=0.2787+0.7990 \mathrm{Mg}_{\text {aplic }}$ & 0.906 \\
$\mathrm{~S}^{(1)}$ & $\mathrm{KCl}$ & $\mathrm{S}_{\text {rec }} / \mathrm{S}_{\text {aplic }}=0.040+0.0057 \mathrm{PR}-60$ & 0.955 \\
$\mathrm{P}_{\text {residual }}{ }^{(2)}$ & $\mathrm{Ca}\left(\mathrm{H}_{2} \mathrm{PO}_{4}\right)_{2} \mathrm{HOAc}$ & $\hat{\mathrm{y}}=(0.05+0.0058(\mathrm{PR}-60) \mathrm{D}) \mathrm{e}^{-(0.000513637+0.0000284091(\mathrm{PR}-60)) \mathrm{T}}$ & - \\
$\mathrm{P}_{\text {residual }}$ & ${ }^{(2)}$ & \multicolumn{1}{c}{$=(0.3572 \mathrm{D}) \mathrm{e}^{-\mathrm{kT}}$} & - \\
\hline
\end{tabular}

Source: Prezotti $(2001)^{(1)}$ and Freire $(2001)^{(2)}$ where y $=$ residual $\mathrm{P}$ in $\mathrm{mg} \mathrm{dm}^{-3} ; 0.5+0.0058$ (PR-60) estimates the recycling rate of P by Mehlich-1, D = the $\mathrm{P}$ dose applied at planting or during the formation phase, in $\mathrm{kg} \mathrm{ha}^{-1}$, $\mathrm{T}$ estimates the loss or decrease of available $\mathrm{P}$ as time passes, $\mathrm{T}=$ time in days, and $\mathrm{k}=0.0013$ is constant of the $\mathrm{P}$ soil availability. 


\section{RESULTS AND DISCUSSION}

\section{Comparison of recommendation methods}

Recommendation tables differ widely among each other, indicating that the knowledge on the real crop nutrient demand is limited. Some situations were simulated to evaluate the results brought forth by the System, allocating values to the different considered situations: soil analysis, organic fertilization, addition of

Table 9. Nutrient and sodium quantity added by rain (Aracruz-ES)

\begin{tabular}{lc}
\hline Element & $\begin{array}{c}\text { Quantity } \\
\text { kg ha }^{-1} \text { year }^{-1}\end{array}$ \\
\hline $\mathrm{N}$ & 19.20 \\
$\mathrm{P}$ & 0.29 \\
$\mathrm{~K}$ & 6.19 \\
$\mathrm{Ca}$ & 1.88 \\
$\mathrm{Mg}$ & 1.56 \\
$\mathrm{Na}$ & 20.20 \\
$\mathrm{~S}$ & $11.10^{(1)}$ \\
\hline Source: Neves $(2000){ }^{(1)}$ Value probably inflated by a nearby cellulose plant
\end{tabular}

nutrients by rain and crop residues. The fertilizer quantities recommended by the tables were converted into element quantities to make comparisons between these and the System easier (Tables 13, 14, and 15). All recommendations, except for the one by Magat (1991), observe only N, P, and K (Medina, 1980; Madeira et al., 1998; Sobral, 1998; and Rosa Jr, 2000).

For a hybrid coconut tree up to six years, the $\mathrm{N}$ recommendation of the System is similar to that of EMBRAPA (Sobral, 1998). One exception is the first year, when the System recommendation is lower, due to the less intensive growth stage, and the third year, when the recommendation is higher, due to the increased growth. Nitrogen recommendation at the adult stage was lower than EMBRAPA recommended (Sobral, 1998) and closer to the recommendation of Frutal (Madeira et al., 1998). Phosphorus recommendation by the System is higher for the initial stage (up to the third year) and inferior to the other recommendations from the fifth year on. Potassium recommendation by the System between the $2^{\text {nd }}$ and the $6^{\text {th }}$ year is superior to the other recommendations, suggesting that the plant demand is superior to the recommended quantities by the tables. Recommendations

Table 10. Nutrient and sodium quantity immobilized annually in the stem of the adult hybrid coconut (138 to 160 plants/ha) and of the adult dwarf coconut tree (177 to 203 plants/ha)

\begin{tabular}{lcc}
\hline \multirow{2}{*}{ Element } & Hybrid & Dwarf \\
\cline { 2 - 3 } & & g/plant/year \\
\hline $\mathrm{N}$ & 269.0 & 89.7 \\
$\mathrm{P}^{(1)}$ & 33.6 & 11.2 \\
$\mathrm{~K}$ & 302.4 & 100.8 \\
$\mathrm{Ca}$ & 61.6 & 20.5 \\
$\mathrm{Mg}$ & 50.4 & 16.8 \\
$\mathrm{Na}$ & 28.0 & 9.3 \\
$\mathrm{Cl}$ & 156.6 & 85.5 \\
$\mathrm{~S}^{(1)}$ & 11.2 & 3.7 \\
\hline
\end{tabular}

Source: Ouvrier (1990). ${ }^{(1)}$ Since the experiments were only carried out in sandy soil, the variation of these nutrients according to the soil capacity factor is not known.

Table 11. Immobilized nutrient and sodium in each part of the fruit bunch (dry matter) of the hybrid coconut PB-121 for the production of $1.0 \mathrm{~kg}$ of copra.

\begin{tabular}{lcccccc}
\hline Element & Spikelet & Stalk & Husk & Shell & Albumen & Bunch (total) \\
\hline & \multicolumn{5}{c}{$\mathbf{g ~ k g}^{-\mathbf{1}} \mathbf{~ o f ~ c o p r a ~}$} \\
\hline $\mathrm{N}$ & 0.3965 & 0.1354 & 2.8094 & 0.6894 & 11.9888 & 16.02 \\
$\mathrm{P}^{(1)}$ & 0.0624 & 0.0203 & 0.1756 & 0.0172 & 1.9601 & 2.24 \\
$\mathrm{~K}$ & 2.1288 & 1.0710 & 20.4854 & 1.3845 & 7.0258 & 32.10 \\
$\mathrm{Ca}$ & 0.2262 & 0.0438 & 0.7609 & 0.1264 & 0.2093 & 1.37 \\
$\mathrm{Mg}$ & 0.3650 & 0.1021 & 0.6204 & 0.0517 & 1.1608 & 2.30 \\
$\mathrm{Na}$ & 0.4105 & 0.3063 & 1.7910 & 0.2240 & 0.3235 & 3.06 \\
$\mathrm{Cl}$ & 1.7095 & 0.8564 & 13.7779 & 0.5400 & 1.7888 & 18.68 \\
$\mathrm{~S}^{(1)}$ & 0.0940 & 0.0089 & 0.2107 & 0.0689 & 0.9039 & 1.29 \\
\hline
\end{tabular}

Source: Ouvrier \& Taffin (1985).

(1) Since the experiments were only carried out in sandy soil, the variation of these nutrients according to the soil capacity factor is not known.

Rev. Ceres, Viçosa, v. 58, n.1, p. 90-99, jan/fev, 2011 
for $\mathrm{K}$ in the adult phase lay a little below the recommendation of EMBRAPA(Sobral, 1998).

Due to the fast growth of the dwarf coconut, the N, P, and $\mathrm{K}$ doses recommended by the System from the second year on are superior to the doses recommended in the Sebrae tables (Rosa Jr, 2000), EMBRAPA (Sobral, 1998), and Frutal (Madeira et al., 1998). During the productive phase, without considering fruit husk recycling, $\mathrm{N}$ and $\mathrm{P}$ doses

Table 12. Nutrient and sodium exportation by the fruit bunch parts (dry matter) of the dwarf coconut tree

\begin{tabular}{|c|c|c|c|c|c|c|c|}
\hline \multirow{2}{*}{ Element } & Stalk $^{(1)}$ & Spikelet ${ }^{(1)}$ & Husk $^{(2)}$ & Shell ${ }^{(2)}$ & Albumen $^{(2)}$ & Water $^{(3)}$ & Total \\
\hline & \multicolumn{7}{|c|}{ mg /fruit } \\
\hline $\mathrm{N}$ & 100 & 30 & 600 & 140 & 2,190 & -(2) & 3,050 \\
\hline $\mathrm{P}$ & 20 & 10 & 40 & - & 360 & 10 & 440 \\
\hline K & 520 & 260 & 4,340 & 270 & 1,280 & 270 & 6,950 \\
\hline $\mathrm{Ca}$ & 50 & 10 & 160 & 20 & 40 & 30 & 310 \\
\hline $\mathrm{Mg}$ & 90 & 20 & 130 & 10 & 210 & 10 & 470 \\
\hline $\mathrm{Na}$ & 100 & 70 & 380 & 40 & 60 & 10 & 660 \\
\hline $\mathrm{Cl}$ & 320 & 210 & 2,920 & 110 & 330 & 340 & 4,220 \\
\hline$S$ & 20 & - & 40 & 10 & 170 & 10 & 260 \\
\hline
\end{tabular}

Source: Ouvrier \& Taffin (1985) ${ }^{(1)}$, Le Saint et al. (1987) ${ }^{(2)}$ and Rosa \& Abreu (2000) ${ }^{(3)}$.

Table 13 - Comparison between the System and the main tables for the recommendation of nitrogen, phosphorus, and potassium for the hybrid coconut tree

\begin{tabular}{|c|c|c|c|c|}
\hline \multirow{3}{*}{$\begin{array}{l}\text { Age (year) and } \\
\text { production }\end{array}$} & System $^{(1)}$ & EMBRAPA & Frutal & Magat \\
\hline & \multicolumn{4}{|c|}{ g /plant } \\
\hline & \multicolumn{4}{|c|}{ Nitrogen } \\
\hline hole & 63 & $132^{(3)}$ & $100^{(3)}$ & $70^{(3)}$ \\
\hline 1 year & 174 & 440 & 150 & 100 \\
\hline 2 years & 748 & 616 & 150 & 150 \\
\hline 3 years & 1,261 & 704 & 350 & 200 \\
\hline 4 years & 879 & 792 & 350 & 300 \\
\hline 5 years & 1,020 & 968 & 500 & 400 \\
\hline 6 years & 1,150 & 1,144 & 500 & 400 \\
\hline \multirow[t]{2}{*}{ production } & 748 & 1,320 & 650 & 400 \\
\hline & \multicolumn{4}{|c|}{ Phosphorus $^{(2)}$} \\
\hline hole & 220 & $70^{(3)}$ & $63^{(3)}$ & $35^{(3)}$ \\
\hline 1 year & - & 35 & 63 & 43 \\
\hline 2 years & 309 & 104 & 63 & 65 \\
\hline 3 years & 369 & 104 & 98 & 70 \\
\hline 4 years & 145 & 174 & 98 & 90 \\
\hline 5 years & 113 & 174 & 146 & 130 \\
\hline 6 years & 76 & 209 & 146 & 130 \\
\hline \multirow[t]{2}{*}{ production } & 157 & 278 & 152 & 130 \\
\hline & \multicolumn{4}{|c|}{ Potassium } \\
\hline hole & 44 & $97^{(3)}$ & $97^{(3)}$ & $117^{(3)}$ \\
\hline 1 year & 183 & 291 & 291 & 170 \\
\hline 2 years & 915 & 388 & 291 & 239 \\
\hline 3 years & 1,533 & 485 & 388 & 304 \\
\hline 4 years & 1,280 & 680 & 388 & 435 \\
\hline 5 years & 1,533 & 777 & 534 & 522 \\
\hline 6 years & 1,769 & 874 & 534 & 522 \\
\hline production & 895 & 971 & 631 & 522 \\
\hline
\end{tabular}

(1) Soil analysis: $\mathrm{P}=20 \mathrm{mg} \mathrm{dm}^{-3}$ (Mehlich-1), $\mathrm{K}=30 \mathrm{mg} \mathrm{dm}^{-3}, \mathrm{~S}=6 \mathrm{mg} \mathrm{dm}^{-3}, \mathrm{Na}=7 \mathrm{mg} \mathrm{dm}^{-3}, \mathrm{Ca}=0.6 \mathrm{cmol}_{\mathrm{c}} \mathrm{dm}^{-3}, \mathrm{Mg}=0.1 \mathrm{cmol}_{\mathrm{c}} \mathrm{dm}^{-3}, \mathrm{PR}-$ $60=50 \mathrm{mg} \mathrm{L}-1$ ans LD = $2.0 \mathrm{t} / \mathrm{ha}$, depth $0-20 \mathrm{~cm}$, and $\mathrm{P}=10 \mathrm{mg} \mathrm{dm}{ }^{-3}$ (Mehlich-1) and $\mathrm{P}=10 \mathrm{mg} \mathrm{dm}^{-3}\left(\mathrm{Mehlich}^{-1}\right), \mathrm{K}=20 \mathrm{mg} \mathrm{dm}{ }^{-3}, \mathrm{~S}=15$ $\mathrm{mg} \mathrm{dm}{ }^{-3}, \mathrm{Na}=5 \mathrm{mg} \mathrm{dm}^{-3}, \mathrm{Ca}=0.3 \mathrm{cmol}_{\mathrm{c}} \mathrm{dm}^{-3}, \mathrm{Mg}=0.1 \mathrm{cmol}_{\mathrm{c}} \mathrm{dm}^{-3}$, organic fertilization: $5 \mathrm{~kg}$ dung with $50 \%$ moisture in the planting hole, $10 \mathrm{~kg}$ from the $1^{\text {st }}$ to the $3^{\text {rd }}$ year, $20 \mathrm{~kg}$ from the $4^{\text {th }}$ to the $6^{\text {th }}$ year, and $30 \mathrm{~kg}$ at the adult stage, recycling the fruit bunches $(160$ plants/ha and $5 \mathrm{t} / \mathrm{ha} /$ year of copra). Recommendations for $\mathrm{P}$ take the residual effect of the previously applied $\mathrm{P}$ doses into consideration.

(2) Opposite to the System, the recommendations for the planting hole do not pay heed to the size of the planting hole. 
recommended by the System are inferior to those of the tables (Tables 13 and 14), while the $\mathrm{K}$ doses are superior, since high quantities of this element are exported via fruits.

The System recommends higher doses of $\mathrm{Mg}$ for the plants at two and three years of age, since the most intensive growth phase lies between 19 and 40 months, while Magat (1991) recommends increasing doses. Up to seven years, the two recommendations for the totally applied $\mathrm{Mg}$ doses are similar. The recommended $\mathrm{Mg}$ dose by the System for adult plants is well below the dose

Table 14 - Comparison between the main tables and the System for nitrogen, phosphorus, and potassium recommendations for the dwarf coconut tree

\begin{tabular}{|c|c|c|c|c|}
\hline \multirow{3}{*}{$\begin{array}{l}\text { Age and } \\
\text { production }\end{array}$} & System $^{(1)}$ & EMBRAPA & Frutal & SEBRAE \\
\hline & \multicolumn{4}{|c|}{ g / plant } \\
\hline & \multicolumn{4}{|c|}{ Nitrogen } \\
\hline hole & 63 & $132^{(3)}$ & $100^{(3)}$ & - \\
\hline 1 year & 246 & 440 & 150 & - \\
\hline 2 years & 339 & 616 & 150 & 440 \\
\hline 3 years & 596 & 704 & 350 & 484 \\
\hline 4 years & 642 & 792 & 350 & 616 \\
\hline 5 years & 1,057 & 968 & 500 & 748 \\
\hline \multirow[t]{2}{*}{ production } & 590 & 1,320 & 650 & 748 \\
\hline & \multicolumn{4}{|c|}{ Phophorus $^{(2)}$} \\
\hline hole & 220 & $70^{(3)}$ & $63^{(3)}$ & $70^{(3)}$ \\
\hline 1 year & - & 35 & 63 & - \\
\hline 2 years & 271 & 104 & 63 & 35 \\
\hline 3 years & 309 & 104 & 98 & 104 \\
\hline 4 years & 83 & 174 & 98 & 104 \\
\hline 5 years & 227 & 174 & 146 & 174 \\
\hline \multirow[t]{2}{*}{ production } & 132 & 278 & 152 & 174 \\
\hline & \multicolumn{4}{|c|}{ Potassium } \\
\hline hole & 44 & $97^{(3)}$ & $97^{(3)}$ & $117^{(3)}$ \\
\hline 1 year & 399 & 291 & 291 & - \\
\hline 2 years & 782 & 388 & 291 & 388 \\
\hline 3 years & 787 & 485 & 388 & 388 \\
\hline 4 years & 1,442 & 680 & 388 & 485 \\
\hline 5 years & 1,877 & 777 & 534 & 631 \\
\hline production & 1,297 & 971 & 631 & 631 \\
\hline
\end{tabular}

(1) Considering the soil analysis of table 14 and organic fertilization with $5 \mathrm{~kg}$ of dung and a moisture of $50 \%$ in the planting hole, $10 \mathrm{~kg}$ from the $1^{\text {st }}$ to the $3^{\text {rd }}$ year, $20 \mathrm{~kg}$ from the $4^{\text {th }}$ to the $6^{\text {th }}$ year, and at the adult stage $30 \mathrm{~kg}$, without considering the restoral of fruit husks (200 plants/ha and a production of 150 fruits/year). ${ }^{(2)} \mathrm{P}$ recommendations take the residual effect of the previously applied $\mathrm{P}$ doses into consideration. ${ }^{(3)}$ The recommendations for the planting hole, opposite to the System, do not take the size of the planting hole into account.

Table 15 - Comparison between the doses recommended by Magat (1991) and the System for magnesium and chlorine for the hybrid coconut tree

\begin{tabular}{|c|c|c|c|c|}
\hline \multirow{3}{*}{$\begin{array}{l}\text { Age and } \\
\text { production }\end{array}$} & System $^{(1)}$ & Magat & System & Magat \\
\hline & \multicolumn{4}{|c|}{ g/planta } \\
\hline & \multicolumn{2}{|c|}{ Magnesium } & \multicolumn{2}{|c|}{ Chlorine } \\
\hline hole & 60 & 27 & & 66 \\
\hline 1 year & 46 & 47 & 177 & 110 \\
\hline 2 years & 306 & 69 & 613 & 260 \\
\hline 3 years & 348 & 137 & 1,049 & 400 \\
\hline 4 years & 150 & 192 & 1,001 & 530 \\
\hline 5 years & 137 & 220 & 1,207 & 700 \\
\hline 6 years & 117 & 275 & 1,410 & 900 \\
\hline production & 44 & 275 & 845 & 900 \\
\hline
\end{tabular}

\footnotetext{
(1) repeat table 14
}

Rev. Ceres, Viçosa, v. 58, n.1, p. 90-99, jan/fev, 2011 
recommended by Magat (1991), because the Mg quantities found in the husks and residues were taken into account for the calculation of the System doses.

The fertilization recommendation for $\mathrm{Cl}$ by the System is superior to that recommended by Magat (1991) for the entire young stage. Only when the plant reaches adult age, $\mathrm{Cl}$ recommendations become similar (recommendation of the System is a bit inferior).

\section{CONCLUSIONS}

For the fertilization of the planting hole, the recommendations given by the tables do not pay heed to the pit volume. Nitrogen and $\mathrm{K}$ recommendations for the planting hole by the tables are higher, compared to the recommendations brought forth by the System, whereas the $\mathrm{P}$ recommendation is lower.

Due to the fact that the nutrient demand during the production stage is a requirement for stem growth and fruit production only, higher fertilizer doses are recommended for the formation and initial production stage, where there is also root growth and leaf recycling is not taken into account, than for the production stage (adult plant).

The crop demand for $\mathrm{K}$ is very high, and the doses recommended by the System are superior to the table recommendations for the formation and initial production stage.

The System offers the possibility to calculate fertilizer doses according to the form of fruit use. The fruit bunches can either be harvested as a whole, or parts of the fruit cluster (spikelet and stalk) or of the fruit (husks) can be restored, and the released nutrients of these parts are taken into account accordingly.

\section{ACKNOWLEDGEMENTS}

The authors thank the Fundação de Amparo à Pesquisa do Estado de Minas Gerais (FAPEMIG) for the Pos Doctor scholarship to Ecila Mercês de Albuquerque Villani.

\section{REFERENCES}

Alvarez V VH \& Ribeiro AC (1999) Calagem. In: Ribeiro AC, Guimarães PTG \& Alvarez V VH (Eds.). Recomendações para o uso de corretivos e fertilizantes em Minas Gerais - $5^{\text {a }}$ aproximação. Viçosa, CFSEMG/UFV. p.43-66.

Barros NF, Neves JCL, Novais RF \& Pereira PRG (1996) Manejo nutricional de plantas perenes. In: Alvarez V VH, Fontes LEF \& Fontes MPF (Eds.). O solo nos grandes domínios morfoclimáticos do Brasil e o desenvolvimento sustentado. 1.ed. Viçosa, Jard. p.607-614.

Cintra FLD; Leal MLS \& Passos EEM (1992) Root system distribution in dwarf coconuts. Oléagineux, 49:225-234.

Cintra FLD; Passos EEM \& Leal MLS (1993) Avaliação do sistema radicular de cultivares de coqueiro gigante. Oléagineux, 48:453-461.
Freire FJ (2001) Sistema de cálculo do balanço nutricional e recomendação de corretivos e fertilizantes para a cultura da canade-açúcar. Tese de Doutorado. Universidade Federal de Viçosa, Viçosa, 87p.

Kiehl EJ (1995) Fertilizantes orgânicos. Editora Agronômica 'Ceres'. p.143-191.

Le Saint JP \& Nucé de Lamothe M (1987) Les hybrides de cocotier nains: performances et intérêt. Oléagineux, 42:353-362.

Madeira MCB, Holanda SJ, Guedes FX \& Oliveira JF (1998) Coqueiro anão, da produção de mudas à colheita. Natal, EMPARN, 72 p.

Magat SS (1991) Fertilizer recomendations for coconut based on soil and leaf analyses. Philippine Journal of Coconut Studies, 16:25-30.

Medina, JC (1980) Coco I - Cultura. In: Medina JM, Garcia JLM, Martin ZJ, Kato K, Teruo P, Turatti JM, Santos LC, Silva MTC, Canto WL, Neto LCB \& Moretti VA (Eds.) Coco - da cultura ao processamento e comercialização. Série Frutas Tropicais - 5. Campinas, Instituto de Tecnologia de Alimentos (ITAL). p.7-58.

Novais RF \& Smyth TJ (1999) Fósforo em solo e planta em condições tropicais. 1.ed. Viçosa, Universidade Federal de Viçosa, Departamento de Solos. 399p.

Neves JCL (2000) Produção e partição de biomassa, aspectos nutricionais e hídricos em plantios clonais de eucalipto na região litorânea do Espírito Santo. Tese de Doutorado. Universidade Estadual do Norte Fluminense, Campos dos Goytacases. 191p.

Ouvrier M (1990) Evolution de la composition minérale du cocotier hybride PB 121 au jeune âge. Oléagineux, 45:69-78.

Ouvrier M \& Taffin G (1985) Evolution of mineral elements of coconut husks left in the field. Oléagineux, 40:435-437.

Prezotti LC (2001) Sistema para recomendação de corretivos e fertilizantes para a cultura do café arábica. Tese de Doutorado .Universidade Federal de Viçosa, Viçosa. 93p.

Rosa Jr CDRM (2000) Coqueiro (Cocos nucifera): cultivo sob condição irrigada. 2.ed. Recife, SEBRAE/PE. 49p.

Rosa MF \& Abreu FAP (2000) Água de coco: métodos de conservação. Fortaleza, Embrapa - CNPTA / SEBRAE/CE (Documento 37). 40p.

Sobral LF (1998) Nutrição e adubação do coqueiro. In: Ferreira JMS, Warwick DRN \& Siqueira LA (Eds.). A cultura do coqueiro no Brasil. 2.ed. Brasilia, Embrapa-SPI. p.129-158 